\title{
Populism, de-globalization, and media competition: The spiral of noise
}

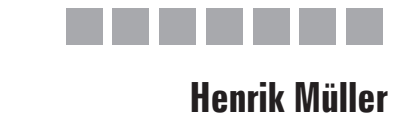

TU DORTMUND UNIVERSITY, GERMANY

DOI: $10.19195 / 1899-5101.10 .1(18) .5$

\begin{abstract}
Populism is increasingly turning against globalization, thereby threatening the stability of the international order. In the vast debate about the causes of the current backlash many factors have been discussed, without explicitly analyzing the role of the media. This paper strives to fill this gap. It focuses on the interaction between politics, economics, and the media in the context of globalization-related issues. In applying a media economic framework it shows that the rise of populism can be interpreted as the consequence of rational choices of different groups of players. The result is a spiral of noise of ever more extreme anti-globalist rhetoric and policies.
\end{abstract}

KEYWORDS: populism, globalization, media economics, agenda setting, media policy.

\section{INTRODUCTION}

There used to be a time when markets were opened up and borders abolished, when international cooperation was enhanced and European integration deepened, when governments and institutions enjoyed high levels of trust. Not long ago, the dominant narrative in Western market democracies, transition countries and emerging markets was one of ever greater economic integration and political cooperation. Globalization took its natural course, facilitated by sophisticated technocrats in politics, business, and finance (Mazower, 2012, pp. 408-410), or so it seemed. In recent years, though, the landscape of the global political economy has changed substantially. Globalization contentment has given place to globalization contempt. Barriers to trade are on the rise (World Trade Organization, 2016). Multinational companies are being forced to produce locally by the introduction of newish localization rules (Bhatia et al., 2016). As a result, from 2012 international trade growth has slowed to levels where globalization intensity is not improving anymore, ${ }^{1}$ lead-

1 Globalization intensity describes the degree of international economic integration. By one measure, globalization intensity increases when trade growth exceeds the growth of the economy (Müller, 2016a). 
ing to a fragile situation that has been dubbed "de-globalization" (e.g. James, 2016). International trade treaties such as TPP, CETA and TTIP have run into full-square opposition in the US and in Europe. Furthermore, migration, another feature of international integration, has suffered from considerable disapproval, stirring resentments against immigrants both from neighboring nations (e.g. Poles living in the UK, Romanians in Germany) and from more distant cultures (e.g. Syria, Afghanistan). ${ }^{2}$ Donald Trump won the 2016 US presidential election on a distinctly anti-globalist platform. The European project, for its part, may well be in a process of dissolution, with Britain's decision to leave the EU being only the most visible sign, while key policy areas such as the Eurozone budget rules or immigration policy are in disarray.

When parallel developments like the ones highlighted in this cursory overview occur on a global scale two questions come to mind: Why? And: Why now? Apparently a tectonic shift against the opening up of economies and societies is underway. But understanding the forces driving this shift is still in its infancy. This paper strives to contribute to this quest by focussing on the changing role of the media and their interaction with national discourses on globalization.

In seeking explanations for the backlash against globalization, economists (e.g. Rodrik, 1997, 2011) and political commentators (e.g. Wolf, 2016) have stressed distributional effects of international market integration. Indeed, conventional measures indicate rising disparities of income and wealth in many countries (e.g. OECD, 2014, pp. 109-111). In a recent study, the McKinsey Global Institute (2016) calculates the shares of people who have suffered from stagnating or falling real incomes in a set of advanced economies. Following this argument anti-globalization sentiment and protectionist policies are direct results of the large numbers of people who have ended up on the losing side of international integration. The global financial crisis of 2008, and the Great Recession followed by a weak recovery only unmasked the distributional consequences of globalization. Political scientists, for their part, have argued that identity issues are at the core of the de-globalization backlash. Immigration in particular raises questions about national identity (e.g. Surel, 2011, p. 4). In the economic sphere competition in the markets for goods and mobile factors of production may lead to insecurity about values and norms; if national habits and attitudes (e.g. work ethics) and the sovereignty of national parliaments (i.e., on priorities in government spending) are challenged for their competitiveness-diminishing properties, economic integration may be deemed undesirable altogether. ${ }^{3}$ Combining economic, political, and cultural factors, Harold

2 Immigration only became a major concern of European citizens in the course of the refugee crisis in 2015 (Eurobarometer, 2015, p. T 29). Before, polls show that Europeans were rather relaxed towards immigration while economic problems dominated the list of concerns (Eurobarometer, 2013, p. T 13).

3 For instance, Marine Le Pen, leader of the French Front National, pleaded for an "intelligent protectionism" to serve French national interests (Der Spiegel, 2014, p. 84). 
James (2009) proposes the concept of a "globalization cycle", a long-term amplitude that can be observed over the past two millennia or so; according to this Hegelianstyle argument international integration produces its own anti-thesis, eventually resulting in the closing of borders and economic deprivation which over time leads to another upswing of globalization.

Due to the complex multifaceted nature of the current de-globalization process it can only partly be explained by the cited approaches. For instance, the distributional effects of globalization have been felt since the 1990s without causing much opposition against free trade. Furthermore, rational politics would not resort to protectionist policies - that are badly suited to counter the distributional effects of globalization as historical experience shows ${ }^{4}$ - but would rather invest in education, skills and infrastructure while keeping borders open. ${ }^{5}$ Why, then, are protectionist approaches in vogue once more?

This paper focuses on a particular feature of the current backlash against globalization: the surge of populism around the world. In its current form, populism tends to have an anti-globalist streak. As a political style that strives to address large parts of society, it relies on mass media. Populism therefore is as much a political as a media phenomenon. This paper strives to analyze the dynamic interactions between politics and the media as far as globalization-related issues are concerned. Populism has been described as a "thin ideology" (Stanley, 2008) that seems to be irrational by relying on political emotions rather than thoroughly weighed arguments. This paper starts from a different hypothesis: Populism, while being detrimental to overall well-being in consequence, may not simply be dismissed as irrational. By applying a media economic approach that is based on micro-economics in the vein of Picard (1989), Shapiro \& Varian (1998) and Hamilton (2004), it seeks to isolate factors that have changed the rational calculus of agents both in the realms of media and politics. By analyzing these factors, mechanisms could be designed to improve political outcomes.

This paper is organized as follows: Section two explores the different forms and styles of populism in politics and in the media. Section three focuses on the specific properties of economic policy issues, particularly of globalization, in the context of populist strategies. Section four investigates the characteristics of the supply and the demand side in globalization discourses. Section five discusses possible implications for journalism and media policy. Section six wraps up the results and draws some conclusions.

${ }^{4}$ During the Great Depression of the 1930s living standards dwindled in the course of a trade war (e.g. Kindleberger, 1986).

5 A case in point is the Nordic model which combines openness with high degrees of redistribution, high education levels and high expenditure on research and development and has worked rather well. 


\section{POPULISM: THE GOOD, THE BAD AND THE UGLY}

Political scientists have stressed that populism comes in a broad range of varieties. ${ }^{6}$ It can be leftist or conservative, internationalist or nationalist, democratic or authoritarian in nature. Despite its different manifestations a set of common features can be isolated: a) Populism tries to build large coalitions of social groups by promoting an image of social unity (i.e., along the lines of nation, class, or religion) that negates specific interests of different groups but stresses a grand "we" the common people sharing a common fate. b) Populism relies on singling out antagonists that are portrayed as enemies of the common people hindering them from leading better lives (Mudde, 2004, p. 543). Elites in government and big business, at European or international institutions, as well as ethnic minorities within a country and other nations can all serve as antagonists. c) Populism focuses on simplistic narratives offering clear-cut answers to complex problems. Costs and side-effects are frequently neglected (Dornbusch \& Edwards, 1991). Proposed solutions typically involve targeting antagonists, or else making them pay. d) Negativity and dramatization prevail. The state of the world outside the populists' reach is framed as decayed and corrupt, to the effect that a contorted version of reality is constructed, the subtext being that only the populist leader has the potential to improve things.

Populism comes in different intensities that could be referred to as good, bad and ugly. To a degree, democratic politics necessarily involve certain aspects of populism. It can be argued that, by reducing the complexity of issues and presenting them in simple words, images and narratives, populist style in its mildest form contributes to the functioning of democracy. Good populism, thus, makes complicated matters accessible to the broad public, i.e., the sovereign. Bad populism, in contrast, leads to inferior political outcomes by neglecting costs and sideeffects. If the longer term consequences of political action are ignored enduringly, heavy burdens will accumulate over time; Italy, for instance, still suffers from Silvio Berlusconi's unwillingness to reform in the 2000s. Bad populism therefore comes with a substantial price tag. Ugly populism is characterized by all of the abovementioned features. Picking on scapegoats has the potential of nurturing suppression and even violence. Real problems are not being solved but aggravated instead, which, in turn, may lead to an even harsher treatment of the perceived enemies of the people. In trying to fashion unity, political opposition as well as the freedom of the press may be stifled. Milder forms of populism may turn ugly over time. In this sense, Turkey's leader Recep Tayyip Erdoğan, who started out as a reformer but has gradually adopted authoritarian characteristics including the suppression of free media, may serve as an example for a good populist turning bad and subsequently ugly.

6 For an overview of the academic debate on populism see Abts \& van Kessel (2015). Historical accounts of populism and populist movements are found in McGrath (2013) and Finchelstein (2014). 
Being a mass-oriented political style, populism needs mass media to address the public (e.g. Moffit \& Tormey, 2014); Mazzoleni (2008) states that populism often relies on some kind of "media complicity". Control of public-service or state-owned broadcasting corporations is not a necessary condition for populist success, even though populists, once in government, often pursue heavy-handed media policies, as can be observed in certain Central Eastern European countries such as Hungary and, more recently, Poland. Market-based media systems also provide large playing fields for populists. Traditional tabloid newspapers in particular have been attributed to pursue populist reporting styles (Mazzoleni, 2003). While elite newspapers tend to explain political, social or economic developments in adequate complexity, tabloids, under pressure to sell in competitive markets, need to catch their audience's attention by presenting emotionally touching stories. Media populism focuses on individuals, not on complex political, economic, or social developments. Furthermore, it is characterized by simplifying issues in a black-and-white manner. Negativity is deemed to be more attention-arousing than balanced reporting. It typically takes an underdog angle of the less-privileged who are portrayed as being exploited by the elites. As shown by Rooduijn (2014) for several European countries, debates in the media have become more populist over the years, the degree of media populism being strongly related to the success of populist parties.

In current media systems not just tabloids compete for attention. Other media, such as privately owned television and online news sites, pursue equivalent strategies. Furthermore, the rise of social media, such as Facebook and Twitter, enables politicians to by-pass journalism and to communicate with their followers directly, and vice versa, thereby influencing public opinion that may then feed back into classic media to the effect that "agenda setting can no longer be understood as a monopoly of the mainstream media, indexed to the actions of political elites" (Boynton \& Richardson, 2016, p. 1918). Journalism's classic role as watchdog and gatekeeper is likely being diminished substantially (Donsbach, 2014, pp. 661-662). During the Brexit campaign in the United Kingdom in the first half of 2016, the interaction of different kinds of media could be observed with tabloids (Barnett, $2016)^{7}$ as well as social media driving public opinion (Mullen, 2016). As in other countries, the refugee crisis in the second half of 2015 and immigration in general were major issues that dominated the debate (Geddes, 2016).

\section{GLOBALIZATION AS A POPULIST ISSUE}

Globalization in a narrow sense involves the integration of product and capital markets as well as increasing migration flows; in a broader sense it also encompasses trans-border flows of information, ideas, and technology (James, 2008, p. 423). Compared with a situation of national autonomy, globalization alters pol-

7 For the role of British tabloids in general see also Cross (2014). 
itical discourses in several dimensions that lend themselves to populisms. In particular, it intensifies the interaction with strangers both through competition in international markets and through immigration. It is largely driven by international corporations that engage in international trade and diversify their production base across borders, and by institutions such as central banks whose actions produce substantial trans-border spillovers. It increases the complexity of policy choices by introducing additional constrains and by diminishing the predictability of outcomes. As empirical studies (e.g. Elchardus \& Spruyt, 2016) indicate, support for populism does not seem to stem mainly from dissatisfaction with the economic situation or with one's personal situation. It is rather the result of a negative view of the evolution of society in general, of the state of a country or the world in general. Globalization is so complex an issue that citizens cannot observe its manifestations directly but can only gauge its implications from the narratives presented to them via the media. Populist strategies build on these properties in constructing simplistic, negativistic narratives that reduce perceived complexity by emphasizing unambiguously antagonistic relationships of the "common people" both with foreign "strangers" and with the elites at the helm of international corporations and institutions.

Economic issues are at the core of populist politics (e.g. Rode \& Revuelta, 2014). Redistributive objectives often take center stage (Dornbusch \& Edwards, 1991). Populists promise short-cuts to the enhancement of common people's well-being largely neglecting scarcities of resources and secondary effects of interventions. Economic policy choices, though, typically involve some kind of trade-off over time. For instance, costs (e.g. induced by painful structural reforms) have to be faced immediately and with certainty while benefits (e.g. higher growth rates) may accrue only later, and with considerable uncertainty. High minimum wages may raise incomes of the lowly paid initially, but may lead to higher unemployment later. Nationalizing certain industries may be popular in the short run, but is likely to dampen investment in the long run. Macro-economic policies are especially prone to populist intervention. While benefits (e.g. of raising government spending) are felt immediately, incurring costs (e.g. higher debt levels) only materialize with considerable delay. Loose monetary policy may fuel economic growth and loosen budget constrains for a while, but is likely to lead to inflation ${ }^{8}$ or asset price bubbles later. Populists tend to ignore these constrains and alter economic institutions, such as independent central banks, accordingly (Rode \& Revuelta 2014; Müller, 2016b).

Globalization adds further constrains to economic policy. Free trade in goods, unrestrained movement of people and capital may result in long-term overall benefits. But the integration of international markets also puts competitive pressure on societies. In terms of communication style, globalization is an ideal target. Workers in declining industries and regions can be portrayed as victims, the culprits being

8 See Bittencourt (2012) for an account of hyperinflation and populist politics in Latin America. 
reckless, self-serving technocratic elites in charge of economic policy at home (as could be observed in the aftermath of the financial crisis of 2008) and unfair competitors abroad (surplus countries such as China), a narrative Donald Trump put forward in the US presidential campaign 2016. The imponderability of globalization in all its complexity all but vanish from discourse. In such a radically simplified setting the adequate political solutions look straightforward: introducing tariffs on imports from countries with a trade surplus vis-à-vis the US, stopping immigration by building walls and fences at the border, deporting unwanted aliens. To be sure, such measures would involve direct costs, e.g. higher prices for imported goods to be faced by consumers, and would risk retaliatory actions by foreign governments. But these side effects fail to make an impression on populists. Alternative approaches such as improving education or introducing new transfer schemes to compensate the losers of international competition, while being superior from an economic perspective, are inferior in terms of politics: first, financing extra government outlays would entail raising government revenues which would likely run into fierce opposition by taxpayers; second, benefits of these programs would be felt only long-term, third, the narrative about victims and culprits is a better story both from a political and from a media perspective.

\section{SUPPLY AND DEMAND DYNAMICS: THE SPIRAL OF NOISE}

Economic policy issues, if addressed thoroughly, imply rather complex mechanisms and policy choices that are hard to be understood by the broader public. Considerable effort, time, and money is needed to appreciate stories on economic issues in adequate depth. From a media economic perspective substantial information costs have to be borne by the consumers of quality journalistic products. These costs not only comprise expenses for the purchase of quality journalistic products such as newspapers, but also opportunity costs in terms of time, a limited resource, not being spent for more pleasant purposes such as leisure or entertainment. If entertaining content is available at a low price, its use tends to be preferred to hard news, thus prompting media companies to downsize their hard news programs and to shift to soft news and entertainment instead (Hamilton, 2004, p. 10). In recent decades, the proliferation of TV channels, websites and, more recently, social media on offer has considerably raised the opportunity costs of the perception of hard news in general and of economic issues in particular.

On the supply side of the market for political issues two groups of agents interact: politicians and media companies. Let's start with the media. To keep the analysis simple, a purely market-based media system is assumed in which profit-oriented firms compete in a market where the main source of income is advertising revenues. Since hard news is an experience good (Nelson, 1970), i.e., consumers cannot gauge quality prior to consumption, there are considerable barriers to market entry; incumbents enjoy the advantage of customer experience and legacy while 
newcomers have to be prepared to endure potentially high costs until, if ever, consumers trust their products. Furthermore, trustworthy hard news is expensive to produce, since large staffs of specialized journalists have to be employed. Traditional production and distribution technologies such as printing presses and ana$\log$ broadcasting networks add to high levels of fixed costs. Economies of scale prevail where unit costs fall with greater usership, raising profits and subsequently additional investments in quality. Therefore, according to the well-known adaption of the Hotelling model of locational competition (Hotelling, 1929), traditional journalism markets tend to be oligopolistic; a limited number of media companies compete to maximize their reach and thus their revenues. To capture a market share as large as possible suppliers typically cluster somewhere around the center of the political spectrum. Trust is earned by independent reporting. Market positions are bolstered by investments in journalistic quality. Indeed, traditional journalistic markets by and large have worked this way for many decades, with a limited number of newspapers or broadcasters competing to maximize reach, leaving customers with little choice (Hamilton, 2004, chap. 1).

In recent decades, though, structural changes have altered the supply side of media markets drastically (Nielson, 2016). Digitization has diminished the revenue base of news companies and at the same time lowered barriers to entry. Formerly oligopolistic news markets have become more competitive with more and more companies trying to capture the audience's attention. Dwindling revenues have led to cost cutting, shrinking editorial staffs. While news has become a commodity that can be obtained free of charge online, hard news and especially in-depth research and analysis struggle to find paying audiences. Independent reporting is costly. Instead of engaging in the costly enterprise to research and produce original stories, herd behavior has become a widespread phenomenon because it comes at a cost advantage; surfing the waves of issue attention cycles (Downs, 1972) promises to catch the audience's attention at a small cost and with little risk. Greater choice has lead parts of the audience to consume more entertaining light news while abandoning hard news (Hamilton, 2004, chap. 3). Social media enable politicians and other agenda setters to bypass classic media when trying to kick off a debate. Traditional media struggle to keep up with the tides of attention. Instead of competing for quality, many media outlets have made maximizing attention at low cost their main objective, trying to capture a share of the remaining pie of advertising budgets.

This is where politicians come in. The current media market environment suits populist strategies, as discussed in section 2, well. Herd behavior among journalism outlets gives politicians and other agenda setters the potential to trigger debates in vast parts of the public. Media companies' economic necessity to maximize usership plays into the hands of anti-elite sentiments pretending to side with the common people who are, supposedly, exploited by the bigwigs. Emotionalizing issues promises better results in attracting the public's attention than dry facts-based reporting. Users' declining attention spans do not bode well for adequately com- 
prehensive explanations of complex issues; instead easy-to-understand narratives that sport friends-and-foes patterns have a competitive advantage. Exaggerated negativity sells better than sober consideration.

While traditional quality media reporting strategies scrutinize politicians' contentions and conduct, in the current media environment even outright lies have a chance to prevail. ${ }^{9}$ Audiences in the habit of primarily consuming light news and entertainment, may expect the same easy-to-use capacities from politics. With attention maximization at low costs being the overwhelming objective of many media companies, live coverage of populists' rallies may suffice. ${ }^{10}$ If polarizing figures are the best show in town, why not tune in directly?

Globalization, as mentioned above, is an ideal playing field for populists. Since complexity is high, its manifestations are costly to comprehend and rather abstract, thus unchecked by individual experience. Alleged culprits often include people in distant places without access to the particular national public, lacking the ability to counter populist attacks. Globalization-related topics are thus prone to negativistic narratives that are distorted images of reality.

Cash-strapped journalism outfits tend to lack the resources to check facts and relationships maintained by populists. Even if fact-checking is done extensively and thoroughly, as was the case during the 2016 US presidential election campaign, it may not alter the course of the debate. This is not surprising due to the extra costs consumers of news have to bear when processing the additional information. Significant parts of the public may, therefore, choose to stick to a strategy of rational ignorance (Downs, 1957) or even rational irrationality (Caplan, 2006). In the processes of agenda setting and agenda building (e.g. Perloff, 2014, pp. 119-153), then, the accuracy of facts matters less than the overall narrative provided by populist politicians, that, in turn, may be anchored in economic interests (Hardin, 2009, pp. 200-201). In consequence, journalistic fact-checking of populist narratives may well broaden their reach, however false the presumptions may prove to be. Once these narratives gain some traction, cascade effects (Hirshleifer, 1995) may set in, so that believing in the populist narrative becomes a social norm among a rising number of people, a result that Hirshleifer (1995, p. 188) refers to as "localized conformity". Furthermore, in an environment of highly competitive news markets the ability of traditional elite media, such as the New York Times in the US, to popularize facts-based counter-narratives on their own (Boydston, 2013), seems to

9 For example, the Brexit campaign's claim that British EU contributions would be used to prop up the finances of the National Health Service after leaving the EU, had to be withdrawn ours after the referendum was won, as Ukip leader Nigel Farage called the promise a "mistake" (see http://www. telegraph.co.uk/news/2016/06/24/nigel-farage-350-million-pledge-to-fund-the-nhs-was-amistake/).

10 During the US presidential campaign, even liberal-leaning news channels such as CNN and MSNBC engaged excessively in live broadcasting of Donald Trump events, offering him an opportunity to address a vast public. 
be diminished. Even if journalism outfits muster the resources needed to research and produce related stories, other media may not follow their lead if simplistic populist narratives promise higher returns.

The spiral of noise is set in motion by the need to raise public attention over and over again. Breaking taboos is a tactic to stay in the headlines, as pioneered by Austria's FPÖ leader Jörg Haider (Plasser \& Ulram, 2003). In order to get to center stage, ever more outrageous claims need to be put forward. Insult and defamation, evoking fear and anxiety, stirring xenophobia, prejudice and sexism are parts of the populist arsenal. Media, eager for attention themselves, take up whatever is considered scandalous, not necessarily because the editorial team agrees with a particular position, but because arousing emotions prompt consumers to tune in, either because they agree or because they are enraged. Step by step, a brutalization of public discourses may occur due to priming effects (Kahneman, 2011). Populist stances become familiar and accepted, potentially shifting cognitive schemata and the climate of opinion permanently (Krämer, 2014, pp. 54-57). What was inadmissible before, eventually becomes common ground, pushing the spiral of noise to the next turn.

Some analysts of the interplay of populist politics and journalism (Mazzoleni et al., 2003) have taken a rather sanguine view, stressing that populists would deprive themselves of their mystique over time. Once in power, they have to compromise and are not able to deliver on their earlier bold promises. The divide between biased narratives and reality becomes obvious eventually. The press and the public grow tired of them, to the effect that populism remains an episode that tends to be followed by another rise of technocratic politicians. A "populism cycle" becomes apparent. Dornbusch and Edwards (1991) arrive at a similar conclusion. In a framework, that does not take account of the media environment explicitly, they stress that populist governments, negating economic constrains (see section 3), at some point have to face the costs their overly simulative macro-economic policies entail (wrecked public finances, inflation) and are removed from office. ${ }^{11}$

Under current conditions, though, more pessimistic outcomes are likely. Selfcorrecting mechanisms cannot be relied upon. The coalescence of populist politics and media may mislead the public for extended periods of time. Markets dominated by journalism outlets, that prefer setting the stage for populists to assess their positions rigorously and providing counter-narratives, cease to act as a corrective arm of public discourse, but become amplifiers instead. Another reason for pes-

11 Drawing from Latin American experience, Dornbusch and Edwards (1991) observe that frequently the International Monetary Fund (IMF) has to step in. Technocratic successor governments have to fix public finances and the currency by implementing strict IMF conditionality. This, in turn, stirs another wave of public discontent, paving the way for the next populist movement. Indeed, currently the populist cycle seems to be in its technocratic phase, with Chavist Venezuela being in disarray and technocratic governments coming to power elsewhere, most notably in Argentina (Rathbone, 2016). 
simism is the nature of de-globalization policies itself: the adverse effects of measures leading to a lingering disintegration of international markets, i.e., barriers to trade, capital flows and migration, may become visible only long-term, until then concealing costly side-effects.

\section{IMPLICATIONS FOR JOURNALISM AND MEDIA POLICY}

The rise of anti-globalist populism on an international scale is not necessarily associated with an outburst of irrationality. In fact, the dynamics that drive the spiral of noise are based on perfectly rational choices by all groups of players involved: media users maximize utility by avoiding hard news whose consumption is associated with increased costs; media companies strive to maximize profits, irrespective of ideological dispositions; politicians maximize public support by addressing large parts of the electorate. In this framework, populism and de-globalization result from the interactions of rational agents. Therefore, it is straightforward to conclude that overall policy outcomes could be improved by altering incentives. Three lines of actions are outlined briefly.

First, if consumption costs are a hindrance to the use of quality media, these costs should be alleviated. This is foremost the job of journalists: telling stories in easy-to-comprehend ways without degrading complexity unduly. Pure fact-checking of claims made by populist agenda setters, though an important aspect of journalism practice, is not sufficient. To prevent the public from being misled, alternative evidence-based narratives need to be put forward by quality media. Covering global economic policy not only requires journalistic skills but also a decent understanding of the mechanisms involved. Specialized journalism programs and midcareer training could help improve coverage by enabling professionals to produce high-quality content, even under more constrained working conditions (Donsbach, 2014, pp. 667-673). Another approach to lowering consumption costs would be raising overall education levels; the more knowledge a person has accumulated, the quicker she (or he) is to grasp stories about complicated topics, and may even take pleasure in consuming hard news (Hamilton, 2004, p. 34).

Second, if fierce competition of profit-oriented media companies leads to deteriorating quality, enhancing the set-up of media systems should be an objective. In the spiral of noise scenario only media companies of the commercial type interact. The coexistence of public-service broadcasting corporations, as in North/Central European media systems (Hallin \& Mancini, 2004, pp. 165-170), may improve the system as a whole. By setting quality standards that private companies cannot undercut without risking their reputation, activities of public broadcasters may prevent a race to the bottom. ${ }^{12}$ Adding further pillars to media systems, such as

12 Yet, even countries with, by and large, autonomous public broadcasters, such as Switzerland and Austria, have seen the rise of populist parties like SVP and FPÖ. In the UK, the BBC, itself under 
not-for-profit journalism outfits financed by foundations, crowd funding, donations or venture capital as well as European (Müller, 2017c) and international quality media, could serve as circuit breakers for the spiral of noise as well.

\section{CONCLUSIONS}

This paper set out to explore the forces behind the current backlash against globalization by including the media into the analysis. We find that the consequences of intense media competition due to digitization play into the hands of populist politicians, especially in the context of globalization-related issues. In a media economic setting, production and consumption of journalistic products about issues of high complexity, such as globalization, are associated with considerable costs. The motive to lower these costs paves the way for simplistic populist narratives about the impact of globalization. Thus, the dynamic interplay of politics and the media can result in a spiral of noise where the mutual quest for attention leads to ever more extreme rhetoric and anti-globalist policies. That is not to say that other factors, such as income distribution or deep-rooted xenophobia, are irrelevant in causing resistance to globalization. But by isolating media economic factors we find that they, too, play a role in the current environment, and potentially a decisive one. The results offer a cause for optimism. If populist dynamics can partly be explained by rational choices, made by media producers and consumers as well as politicians, then changes in the incentive structure should lead to economic policy outcomes that are more viable and less risky.

This paper has drawn from different strands of social science, foremost from media economics. A formal formulation of the spiral of noise model would be a worthwhile exercise. One road to take when empirically validating this approach could be to compare populist politics and media systems, controlling for the economic and social impact of globalization in different countries. If not rejected, the explanatory power of the media economy-based approach to populism could be quantified.

\section{REFERENCES}

Abts, K., van Kessel, S. (2015). Populism. In: International Encyclopedia of the Social \& Behavioral Sciences, 2nd edition, Volume 18., Amsterdam, Boston, Heidelberg, London, New York, Oxford, Paris, San Diego, San Francisco, Singapore, Sydney and Tokyo: Elsevier, pp. 609-612.

Barnett, S. (2016, June). How our mainstream media failed democracy. In: Jackson, D., Thorsen, E., Wring, D. (eds.). EU Referendum Analysis 2016: Media, Voters and the Campaign. Early Reflections from Leading UK Academics. The Centre for the Study of Journalism, Culture and Community. Poole: Bournemouth University, p. 47.

political pressure, was not able to counter the 2016 Brexit campaign effectively (Renwick \& Flinders, 2016). 
Henrik Müller

Bhatia, K., Evenett, S.J., Hufbauer, G.C. (2016, June 21). Why General Electric is localising production. Retrieved August 28, 2016 from http://voxeu.org/article/ why-general-electric-localising-production.

Bittencourt, M. (2012). Democracy, populism and hyperinflation: Some evidence from Latin America. Economics of Governance, 13, pp. 311-332.

Boydston, A.E. (2013). Making the News: Politics, the Media, and Agenda Setting. Chicago, IL: University of Chicago Press.

Boynton, G.R., Richardson, G.W. Jr. (2016). Agenda setting in the twenty-first century. New Media \& Society, 18 (9), pp. 1916-1934.

Caplan, B.D. (2006). The Myth of the Rational Voter: Why Democracies Choose Bad Policies. Princeton, NJ: Princeton University Press.

Cross, S. (2014). Mad and bad media: Populism and pathology in the British tabloids. European Journal of Communication, 29 (2), pp. 204-217.

Der Spiegel (2014). “Achtung, Frau Merkel!“. Interview with Marine le Pen. Der Spiegel, 23, pp. 82-85.

Donsbach, W. (2014). Journalism as the new knowledge profession and consequences for journalism education. Journalism, 15 (6), pp. 661-677.

Dornbusch, R., Edwards, S. (1991). The macroeconomics of populism. In: Dornbusch, R., Edwards, S. (eds.). The Macroeconomics of Populism in Latin America. Chicago, Il.: Chicago University Press, pp. 7-13.

Downs, A. (1957, April). A theory of political action in a democracy. The Journal of Political Economy, 65 (2), pp. 135-150.

Downs, A. (1972). Up and down with ecology - the issue-attention cycle. The Public Interest, 0 (28), pp. 38-50. Retrieved July 22, 2016 from http://search.proquest.com/docview/1298108041/6B5A 4136FD5645FEPQ/6? accountid=14531.

Elchardus, M., Spruyt, B. (2016). Populism, persistent republicanism and declinism: An empirical analysis of populism as a thin ideology. Government and Opposition, 51 (1), pp. 111-133.

Eurobarometer (2013). Standard Eurobarometer 80. Public Opinion in the EU - Autumn 2013. Annex. Brussels.

Eurobarometer (2015). Standard Eurobarometer 84. Public Opinion in the EU - Autumn 2015. Annex. Brussels.

Finchelstein, F. (2014). Returning populism to history. Constellations, 21 (4), pp. 467-482.

Geddes, A. (2016, June). The referendum and Britain's broken immigration politics. In Jackson, D., Thorsen, E, Wring, D. (eds.). EU Referendum Analysis 2016: Media, Voters and the Campaign. Early Reflections from Leading UK Academics. The Centre for the Study of Journalism, Culture and Community. Poole: Bournemouth University, p. 18.

Hallin, D.C., Mancini, P. (2004). Comparing Media Systems: Three Models of Media and Politics. Cambridge: Cambridge University Press.

Hamilton, J.T. (2004). All the News That's Fit to Sell: How the Market Transforms Information into News. Princeton, NJ: Princeton University Press.

Hardin, R. (2009). How Do You Know? The Economics of Ordinary Knowledge. Princeton, NJ: Princeton University Press.

Hirshleifer, D. (1995). The blind leading the blind: Social influence, fads and informational cascades. In: Ierulli, K., Tommasi, M. (eds.). The New Economics of Human Behaviour. Cambridge, UK: Cambridge University Press, pp. 188-215.

Hotelling, H. (1929). Stability in competition. Economic Journal, 34, pp. 41-57. Retrieved July 20, 2016 from http://people.bath.ac.uk/ecsjgs/Teaching/Industrial\%20Organisation/Papers/Hotelling \%20-\%20Stability\%20in\%20Competition.pdf.

James, H. (2008). Globalization, empire and natural law. International Affairs, 84 (3), pp. 421-436.

James, H. (2009). The Creation and Destruction of Value. The Globalization Cycle. Cambridge, Mass.: Harvard University Press. 
James, H. (2016). Anti-Globalisierung bedeutet Kontrollen und Vergeltung. Süddeutsche Zeitung, August 26, p. 4.

Kahneman, D. (2011). Thinking, Fast and Slow. New York: Farrar, Straus and Giroux.

Kindleberger, C.P. (1986). The World in Depression, 1929-1939. Berkeley, Los Angeles and London: University of California Press.

Krämer, B. (2014). Media populism: A conceptual clarification and some theses on its effects. Communication Theory, 24, pp. 42-60.

McGrath, M. (2013). The histories of populism. National Civic Review, 102 (2), pp. 50-56.

McKinsey Global Institute (2016, July). Poorer than Their Parents? Flat or Falling Incomes in Advanced Economies. London: McKinsey \& Company.

Mazower, M. (2012). Governing the World. The History of an Idea, 1815 to the Present. London, UK: Penguin.

Mazzoleni, G. (2003). The media and the growth of neo-populism in contemporary democracies. In: Mazzoleni, G., Stewart, J., Horsfield, B. (eds.). The Media and Neo-Populism. London: Praeger, pp. 1-20.

Mazzoleni, G. (2008). Populism and the media. In: Albertazzi, D., McDonnell, D. (eds.). Twenty-First Century Populism. The Spectre of Western European Democracy. Basingstoke: Palgrave Macmillan, pp. 49-67.

Mazzoleni, G., Stewart, J., Horsfield, B. (eds.) (2003). The Media and Neo-Populism: A Contemporary Comparative Analysis. Westport, CT: Praeger.

Moffitt, B., Tormey, S. (2014). Rethinking populism: Politics, mediatisation and political style. Political Studies, 62, pp. 381-397.

Mudde, C. (2004). The populist zeitgeist. Government and Opposition, September 27, pp. 541-563.

Mullen, A. (2016, June). Leave versus Remain: The digital battle. In: Jackson, D., Thorsen, E., Wring, D. (eds.). EU Referendum Analysis 2016: Media, Voters and the Campaign. Early Reflections from Leading UK Academics. The Centre for the Study of Journalism, Culture and Community. Poole: Bournemouth University, p. 89.

Müller, H. (2016a). Der neue Kalte Krieg. Manager Magazin, September 2016 issue, p. 87.

Müller, H. (2016b, August 21). Sündenböcke im Geldturm. Retrieved August 21, 2016 from http:// www.spiegel.de/wirtschaft/finanzmaerkte-die-notenbanker-als-suendenboecke-a-1108682.html.

Müller, H. (2017c). Fighting Europe's crisis with innovative media: A modest proposal. Journal of Business and Economics. Forthcoming.

Nelson P. (1970, March-April). Information and consumer behavior. Journal of Political Economy, 78 (2), pp. 311-329.

Nielson, R.K. (2016). The business of news. In: Witschge, T., Anderson, C.W., Domingo, D., Hermida, A. (eds.). The Sage Handbook of Digital Journalism. Newbury Park, CA: Sage, pp. 51-67.

OECD (2014). Society at a Glance. OECD Social Indicators. The Crisis and Its Aftermath. Paris: Organisation for Economic Cooperation and Development.

Perloff, R.M. (2014). The Dynamics of Political Communication. Media and Politics in a Digital Age. New York and London: Routledge.

Picard, R.G. (1989). Media Economics: Concepts and Issues. Newbury Park CA: Sage.

Plasser, F., Ulram, P.A. (2003). Striking a responsive chord: Mass media and rightwing populism in Austria. In: Mazzoleni, G., Stewart, J., Horsfield, B. (eds.). The Media and Neo-Populism: A Contemporary Comparative Analysis. Westport, CT: Praeger, pp. 21-43.

Rathbone, J.P. (2016). Under new management. The region is rejecting populism even as the US and Europe flirt with it. Financial Times, June 22, p. 7.

Renwick, A., Flinders, M. (2016, June). Calming the storm: Fighting falsehoods, fig leaves and fairy tales. In: Jackson, D., Thorsen, E., Wring, D. (eds.). EU Referendum Analysis 2016: Media, Voters and the Campaign. Early Reflections from Leading UK Academics. The Centre for the Study of Journalism, Culture and Community. Poole: Bournemouth University, p. 31. 
Rode, M., Revuelta, J. (2014). The wild bunch! An empirical note on populism and economic institutions. Economics of Governance, 16, pp. 73-96.

Rodrik, D. (1997). Has Globalization Gone Too Far? Washington, D.C.: Institute for International Economics.

Rodrik, D. (2011). The Globalization Paradox: Why Global Markets, States, and Democracy Can't Coexist. Oxford: Oxford University Press.

Rooduijn, M. (2014). The mesmerising message: The diffusion of populism in public debates in Western European media. Political Studies, 62, pp. 726-744.

Shapiro, C., Varian, H. (1998). Information Rules. Cambridge, Mass: Harvard Business Review Press.

Stanley, B. (2008). The thin ideology of populism. Journal of Political Ideologies, 13 (1), pp. 95-110.

Surel, Y. (2011, June). The European Union and the Challenges of Populism. Notre Europe Policy Brief No. 27. Retrieved May 25, 2016 from http://www.institutdelors.eu/media/ bref27_ysurel_en. pdf?pdf $=$ ok.

Wolf, M. (2016). Global elites must heed the warning of populist rage. Financial Times, July 19, p. 9.

World Trade Organization (2016). Report on G20 Trade Measures (Mid-October 2015 to Mid-May 2016). Geneva: The World Trade Organization. 